\title{
Trade and economic integration dominants in North America countries' interaction
}

\author{
Olha Yatsenko \\ Kyiv National Economic University named after Vadym Hetman, \\ Kyiv, Ukraine \\ yacenkoolgakneu@gmail.com \\ Vitalii Nitsenko \\ Private Joint-Stock Company "Higher education institution "Interregional \\ Academy of Personnel Management", Kyiv, Ukraine \\ vitaliinitsenko@gmail.com
}

Tetiana Tananaiko

Kyiv National Economic University named after Vadym Hetman,

Kyiv, Ukraine,

tetiana_tananaiko@ukr.net

\section{Beata Szetela}

Rzeszow University of Technology, Poland

beata@prz.edu.pl

\author{
Alla Kobylianska \\ Kharkiv Petro Vasylenko National Technical University of Agriculture, \\ Kharkiv, Ukraine \\ akobylyanskaya@kse.org.ua
}

Abstract. Under the conditions of deepening economic globalization and changes in regional integration unions functioning, formation and support of mutually beneficial and effective cooperation between countries is an important issue. Despite geographic proximity, cultural similarities and high efficiency of economic interactions, current state of the US-Canada trade cooperation worsens due to the ambitions of the USA as a global economic leader, alongside with unresolved trade disputes and increasing deficit of trade in goods and services. According to the analysis of the US-Canada external trade, it was concluded that due to long-lasting trade, the related supply chains have become highly integrated. The USA buys mostly raw materials and semi-finished products which are then used in

Received: February, 2019 1st Revision:

May, 2019

Accepted: September, 2019

DOI:

$10.14254 / 2071$ $8330.2019 / 12-3 / 22$ 
finished products designated for internal and external markets. A lot of them even are sold back to Canada. However, there is a controversy in the USA and Canada interests. The USA seeks, first of all, to keep the world leading economic positions, to expand dutyfree market available for the sales of domestic producers etc. Canada intends to get rid of protectionist restrictions presumed in American legislation and, thus, to increase the competitiveness of its producers' of goods at the US markets. Estimating the coefficient of trade connectivity, which is bigger than 1 , it was evidenced that both countries, in case of trade relations' worsening or break, will be hardly reoriented on other partners. Our regression analysis shows that Canada's GDP positively depends on Canadian exports to the USA, while the subsequent permanent increase in Canada's exports to the USA is forecasted. However, it had been argued that the perspectives of future cooperation hardly depend on the results of negotiation regarding NAFTA reforming which turned into USMCA. Despite the positive conclusion of negotiations on NAFTA's reform and its transformation into USMCA/CUSMA, Canada still has to come up with a more rational policy in order not to become the fifty-first state of the US within the currency and, then, political union.

Keywords: globalization, regional integration unions, NAFTA, USMCA, coefficient of trade connectivity, exports, the USA, Canada.

JEL Classification: C01, F13, F17, F21, F53

\section{INTRODUCTION}

Free trade between Canada and the United States existed before Canada actually emerged. In 1855, the first free trade agreement came into force between the British colonies in North America and the United States, which, however, was terminated by the American side in 1866. The following decades were marked by protectionism, but the Great Depression again forced the search for ways to expand sales, and between 1935 and 1980, a number of bilateral trade agreements were concluded that significantly simplified trade and eliminated unnecessary duties. The most important of these was the so-called Automobile Pact of 1965, which introduced virtually complete free trade in the automotive industry of the two states.

The relationship between the USA and Canada have been unequal from the beginning because of the size of the US economy and the potential for serious impact. However, both countries make great efforts to balance such trade-economic relations with a view to let them remain mutually beneficial.

\section{LITERATURE REVIEW}

The works of such scientists as: Kayser (2018), Wilkers (2017), Vring (2013), Greenwood (2018), Lensky (2017), Pelkmans (2016), Molle (2012), Svan (2013) - are devoted to theoretical research of integration processes and peculiarities of formation of regional integration blocs. Conceptual grounds of specifics of formation of FTA as one of the forms of international economic integration are described in 
works of Root (2000), Makogon (2017), Dzialo et al., 2017, Gawronska-Nowak et al., 2019. The issues of NAFTA creation and development, and of problematic aspects of Canada-USA trade relations are considered by such foreign economists as: Peterson (2013), Kim (2018), Fergusson (2014), Hufbauer (2005), - and by domestic ones: Bilan (2009), Vesela (2016), Yatsenko et al., (2017, 2019), Moroz et al., (2017),

However, due to negotiations on improvement in conditions of trade and economic relationship, which have resulted in signing of USMCA (ex-NAFTA), this topic is gaining actuality. Thus, the goal of the research is the characterization and qualitative assessment and forecast of the state and development of trade cooperation between USA and Canada.

\section{METHODOLOGY}

From the methodological point of view the paper proceeds as follows:

1. analysis of sources of mutually beneficial trade relations between Canada:

- research of place Canada and the USA hold in foreign economic activity of each other (external trade volumes, structure of exports in goods and services, FDI flows);

- assessment of the deepness of institutionalization of the US-Canada economic relations (e.g. regulatory partnership in the sphere of ecology, security and health protection);

- overview of history of NAFTA creation;

- definition of chronological stages in NAFTA creation and functioning;

2. assessments of prospects and challenges of NAFTA functioning, including transformation into USMCA:

- analysis of the US-Canada economic relations both within union and with third countries;

- evaluation of tangible issues in the US-Canada economic relations (e.g. in sphere of energetics, dairy products etc.);

- discussion on US foreign economic policy and ambitions as global economic leader at current stage;

- consideration of scenarios for NAFTA reforming into USMCA and making hypothesis on benefits of its preserving;

3. research of degree of economic benefits associated with ex-NAFTA functioning

- evaluation of trade connectivity coefficient basing on methodology suggested by Vanyushkin (Vanyushkin, 2004);

- estimation of dependence of Canada GDP on external trade with the USA;

- forecasting the development of Canada exports to the USA till 2019.

To achieve the goal of the paper such methods are used: historic and logical, system and structural analysis of economic processes and phenomena, method of qualitative and quantitative comparison, comparative and statistical analysis, correlation and regression analysis, time series analysis.

The research is based on data describing foreign economic activities of the USA and Canada (export/import in goods and services volumes and structure, FDI volume and structure, geographical structure of external economic activity etc.) from official and other open sources, including: Official Website of the State Statistics Service of Canada; Official Website of the Statistics Bureau of Canada; Official website of the WTO; Official website of the UNCTAD etc. The research mostly covers period starting from 1990.

\section{EMPIRICAL RESULTS AND DISCUSSION}

Trade and economic relations are defined as relations between countries and integration unions based upon exchange and financial operations and on cooperation and mutual development (Pasmor et al., 2016). According to E.A. Kuleshov, A.P. Kireeva, V. Pan'kov et al, these relations are the most important sphere 
of economic cooperation between countries. Bilateral trade relations are characterized by the existence of long-term cooperation agreed by countries fixed in international agreements.

These relations are more effective under condition of FTA creation. FTA is a zone, where the specific preferential trade regime for participating countries is in place assuming elimination of tariffs, while for the third counties they are still in place (Lukyanenko et al., 2014). Ex-NAFTA is an example of such a zone for the USA, Canada and Mexico.

There were a lot of examples of mutual beneficial and solid relations, while at this point of view one of the most prominent examples is trade and economic cooperation between the USA and Canada. The efficiency of such partnership is explained by the range of causes, as goods and services in overall value of 1.7 USD mln crossed Canada-USA border in 2016 (Fig. 1).

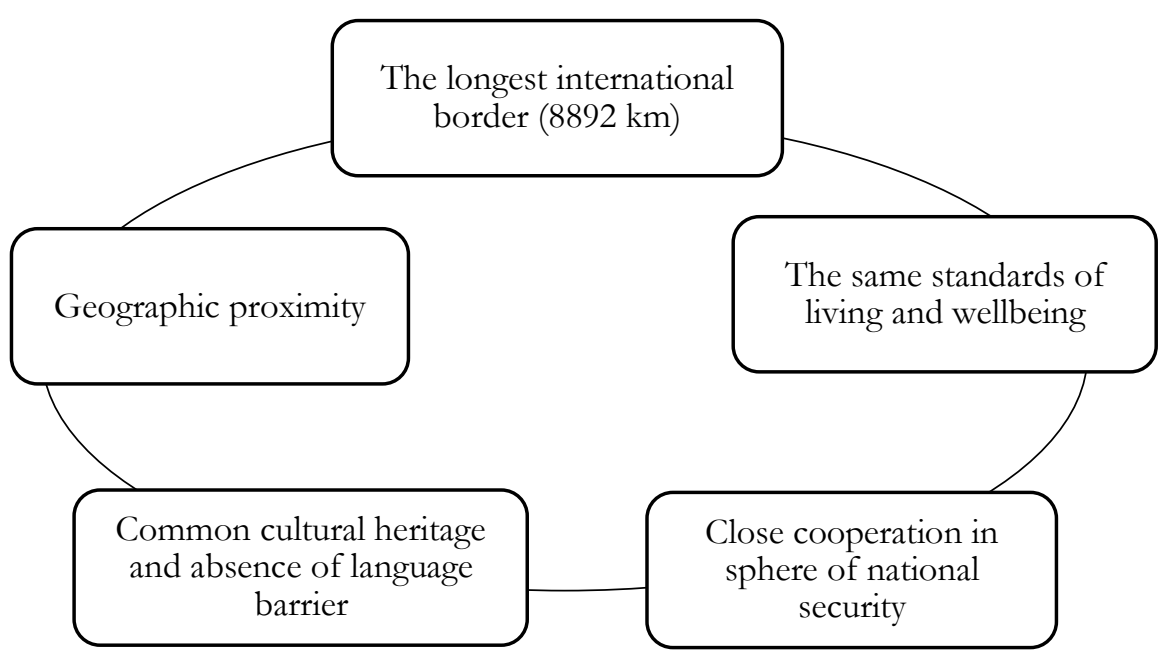

Figure 1. Factors of mutually beneficial USA-Canada trade relations Source: built by authors upon (Desjardins, 2017; Lynch, 2017)

During last decade Canada is one of the biggest trade partners of the USA, being the biggest exporter of 36 of 50 states. Both counties are exporting their commodities and services to the same countries: Mexico, China, Japan, Great Britain (Table 1).

Main countries-importers of American and Canadian products in 2016, \%

\begin{tabular}{|c|l|c|c|l|c|}
\hline \multicolumn{3}{|c|}{ Top-10 importers of US products } & \multicolumn{3}{|c|}{ Top-10 importers of Canada products } \\
\hline 1. & Canada & $18 \%$ & 1. & USA & $76 \%$ \\
\hline 2. & Mexico & $16 \%$ & 2. & China & $4 \%$ \\
\hline 3. & China & $8 \%$ & 3. & Great Britain & $3 \%$ \\
\hline 4. & Japan & $4 \%$ & 4. & Japan & $2 \%$ \\
\hline 5. & Great Britain & $4 \%$ & 5. & Mexico & $1 \%$ \\
\hline 6. & Germany & $3 \%$ & 6. & South Korea & $1 \%$ \\
\hline 7. & South Korea & $3 \%$ & 7. & Germany & $1 \%$ \\
\hline 8. & Netherlands & $3 \%$ & 8. & India & $1 \%$ \\
\hline 9. & Hong Kong & $3 \%$ & 9. & France & $1 \%$ \\
\hline 10. & Belgium & $2 \%$ & 10. & Belgium & $1 \%$ \\
\hline
\end{tabular}

Source: built by authors upon (State Statistics Service of Canada, 2016; Statistics Bureau of Canada, 2016). 
Canada is exporting to the USA $76 \%$ of overall products, while USA - only $18 \%$ (fig. 2). The USA and Canada get huge profit from mutual trade, thus benefits and effectiveness of these relations are undisputable at the moment. Scientists explain this fact by such reasons as: transparency of both economies, free movement of population between countries, long-term cooperation.

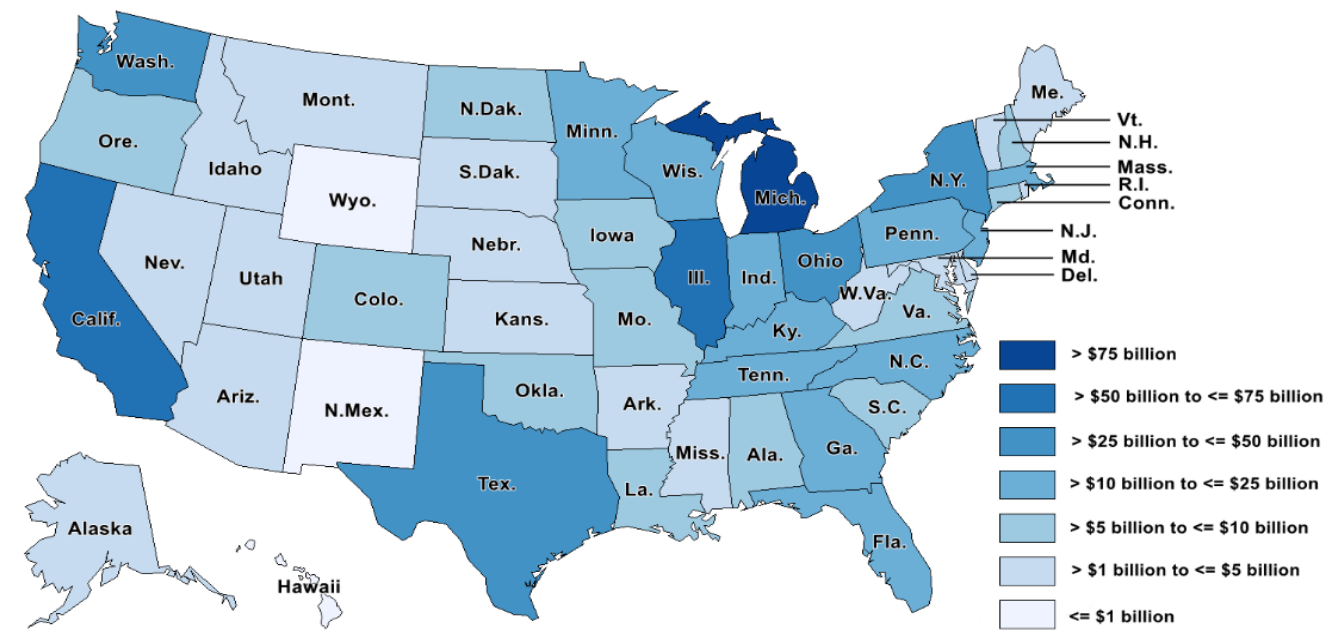

Figure 2. Canada-USA external trade in goods (by states, USD bn) Source: (State Statistics Service of Canada, 2016).

From 1990 to 2016 general volumes of Canada trade with the USA increased three times. The sharpest increase was observed in 1992-2000, when average annual growth rates of external trade turnover exceeded $18 \%$, while export to USA increased by $185.8 \%$, and import - by $138 \%$ (Fig. 3). This expansion was cased by NAFTA signing in 1992 (NAFTA, 1994) and its implementation in 1994.

The overall turnover of Canada trade with the USA was 673 USD bn in 2016, which is $64 \%$ of general volume of Canada external trade with the World. This indicator decreased by $2 \%$ comparing to 2015 , when the record volume of goods (688 USD bn) was sold between countries. Export of Canada to the USA was 394 USD bn in 2016, while import - 278 USD bn, which is $76.3 \%$ of total export of Canada and $52.2 \%$ total import, respectively.

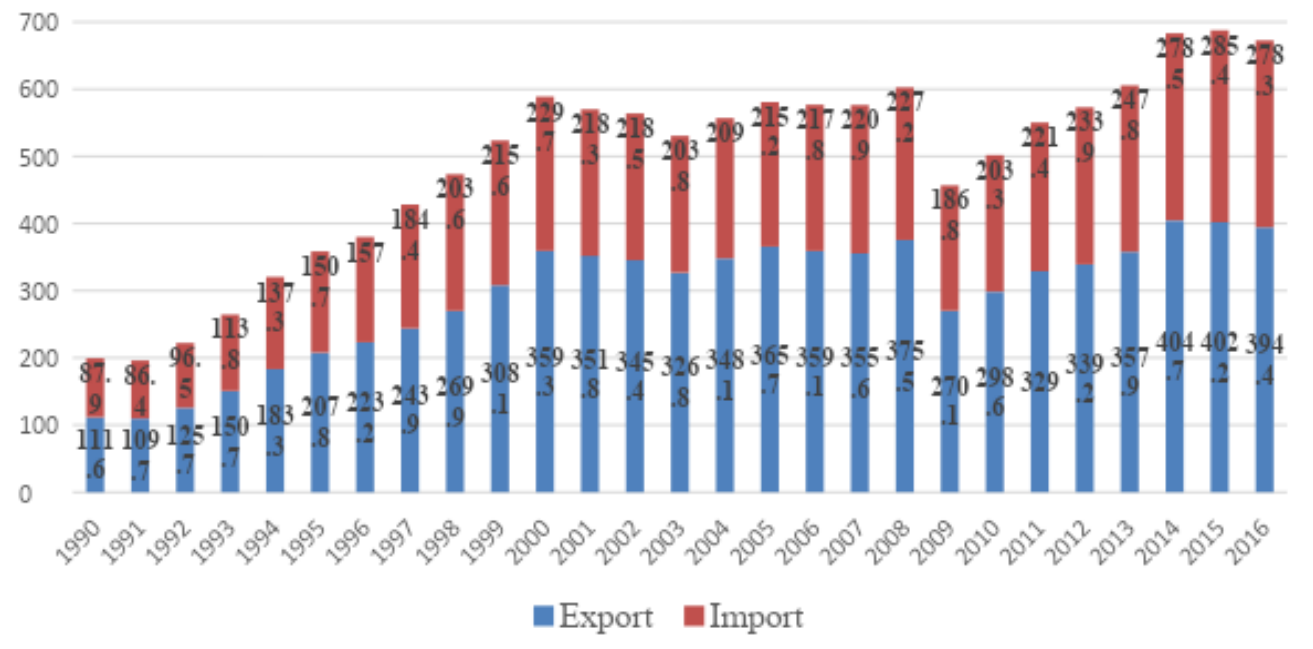

Figure 3. The US-Canada trade turnover in 1990-2016, USD bn

Source: built by authors upon (State Statistics Service of Canada, 2016; Statistics Bureau of Canada, 2016). 
Let's consider the structure of trade illustrated on fig. 4 and fig. 5 within North America region. In 2016 the largest export groups were automobiles (48 USD bn), transport equipment (40 USD bn), electrodevices (24 USD bn), mineral fuels (16 USD bn) and plastics (12 USD bn). USA exported to Canada, its biggest market for agricultural export, 23 USD bn of agricultural products in 2016. The main categories are finished food products (1.9 USD bn), fresh vegetables (1.8 USD bn), fresh fruits (1.6 USD bn), soya snacks (1.3 USD bn) and soft beverages (e.g. juices) (1.2 USD bn). Export of American services to Canada amounted to 54.2 USD bn in 2016, which is $4.0 \%$ lower (2.3 USD bn) than in 2015, but $43.1 \%$ higher than in 2006. In 1993 this indicators increased by 218\% (since the beginning of NAFTA creation). Export of leading services from the USA to Canada in 2016 was represented by those of transport, intellectual property (software and audio-visual support).

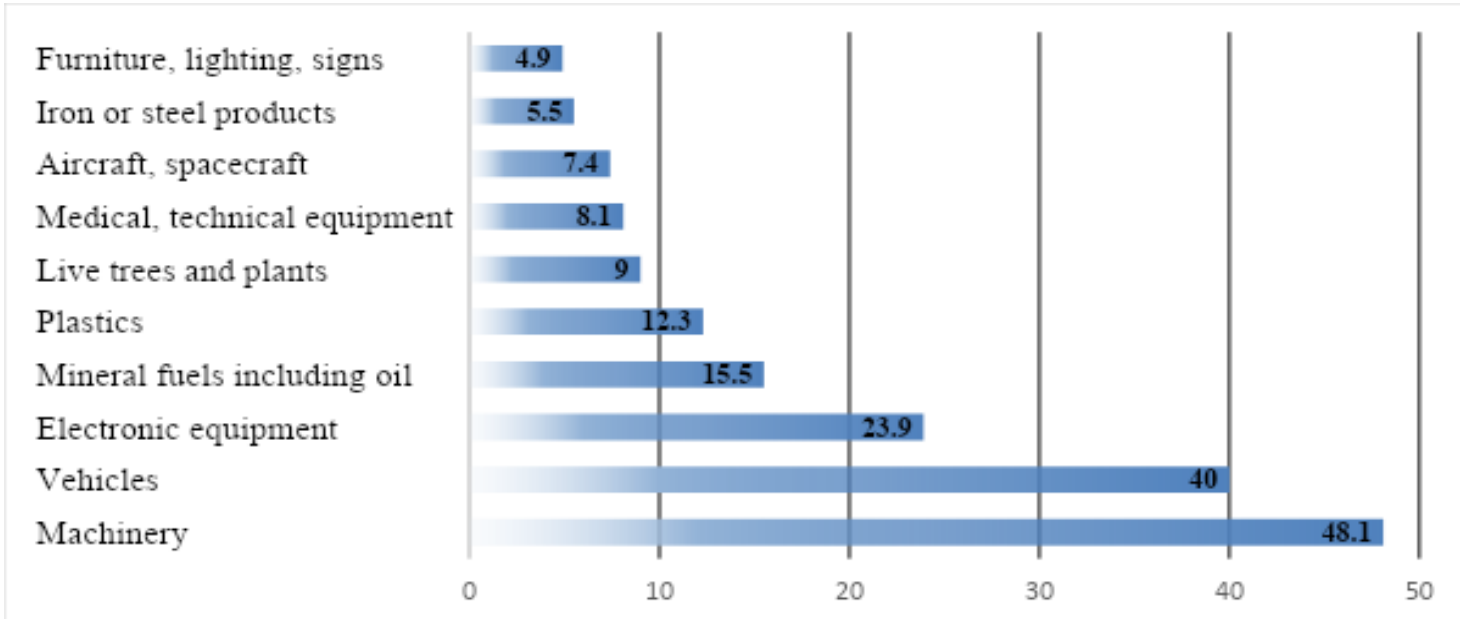

Figure 4. Top-10 US exports to Canada, USD bn

Source: built by authors upon (World's richest countries, 2016).

Canada placed third in supplying goods to the USA in 2016. Thus, the USA importing Canada goods in amount of 278.1 USD bn in 2016, which is $6.1 \%$ (18.1 USD bn) lower than in 2015 and $8.1 \%$ lower than in 2006. The US import from Canada increased by $150 \%$ in 1993. In 2016 the most popular import groups were automobiles (58 USD bn), mineral fuels (54 USD bn), cars and equipment (19 USD bn), specific others (15 USD bn) and plastics (10 USD bn). American import of agricultural products from Canada, the second largest supplier of agricultural products, equated 22 USD bn in 2016. The leading categories in this category are: snacks (4.0 USD bn), meet (2.2 USD bn), other vegetable oils (1.8 USD bn), lived animals (1.5 USD bn), processed fruits and vegetables (1.4 USD bn). The USA import of services from Canada equaled 29.6 USD bn in 2015, which is $2.0 \%$ (585 USD mln) higher than in 2015, and $23.6 \%$ higher than in 2006. Starting from 1993 its volumes increased by almost $225 \%$ (since the creation of NAFTA). In 2015 the USA import of services from Canada was dominated by trips, transport and telecommunications, computer and information services. 


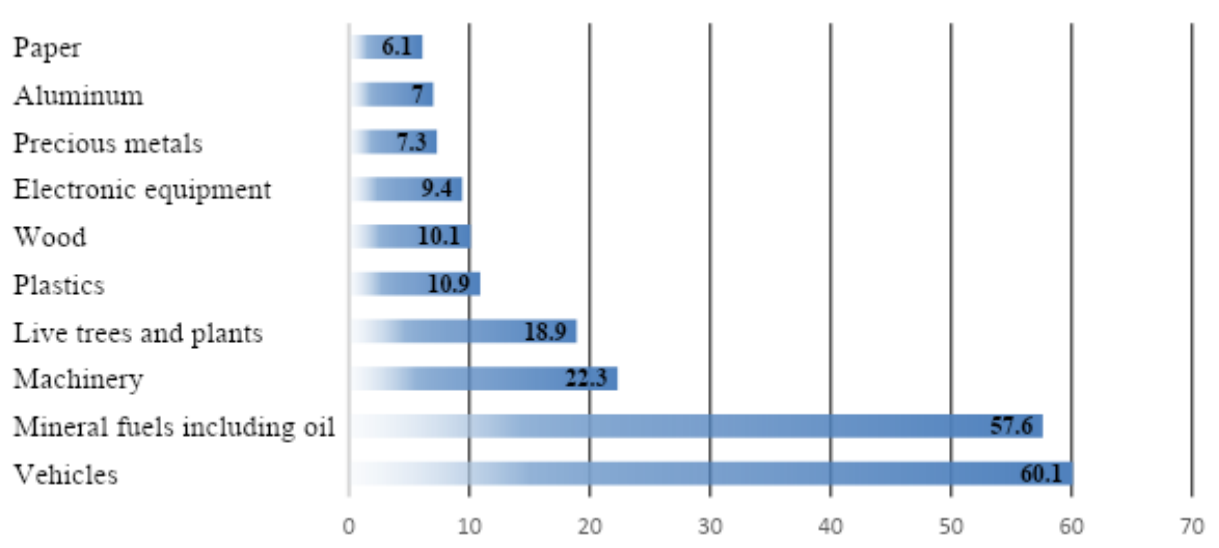

Figure 5. Top-10 Canada exports to the USA, USD bn

Source: built by authors upon (World's richest countries, 2016).

Thus, due to long lasting trade, supply chains between the two countries have become highly integrated. The USA buy mostly raw materials and semi-finished products which are then used in finished products designated for internal and external markets. A lot of them even are sold back to Canada. This is also true for Canada crude oil to reduce dependence on OPEC and for import of hydroelectricity at low prices during heavy precipitation and for use of aluminum for the production of ecologically safe transport.

FDI to Canada were 352.9 USD bn in 2015, which is $1.5 \%$ lower than in 2014. These FDI are directed mostly to production, non-banking holdings, finance and insurance. Canada FDI to the USA in 2015 equated to 269 USD bn, which is $4.6 \%$ higher than in 2014. Canadian FDI are directed to production, finance, insurance and deposit institutions. Sales of services in Canada by the largest US affiliates were 134.5 USD bn in 2014, and those of Canadian companies in UDS amounted to 89 USD bn (State Statistics Service of Canada, 2016). The exchange rate of American and Canadian dollar also influenced the US companies that entered Canadian market. The low exchange rate of Canada dollar led not only to an increase in the quantity of products bought, but also to an increase in investments, especially to automobile sector.

Moreover, the USA and Canada continue deepening regulatory cooperation in order to enhance economic competitiveness, while maintaining high standards in the spheres of health, safety and the environment protection with the help of cooperation between specific narrowly specialized institutions (Table 2).

Canada-America relations in the field of energetics are characterized by spectacular volumes of bilateral trade in amount of 1.9 USD bn per day. Canada ranks third by amount of oil reserves (after Saudi Arabia and Venezuela). Historically Canada is the largest crude oil (25\%) and natural gas exporter to US. However, the pace of these highly integrated energy relations could be altered in the nearest future. The extraction and crude oil and natural gas reserves in USA increased due to the growth of technical development of crude oil and shale gas. Besides, administration of energy information of the USA forecast the slowdown in increase of crude oil and natural gas consumption of the USA in next decades till 2035 (State Statistics Service of Canada, 2016). Thus, Canada would have to look for new export markets.

Summing up, nowadays only few countries have such a degree of economic interdependences, and the degree of integration and value of goods that are circulating make them, perhaps, the closest bilateral trade relations in the world. 
Table2

Institutions- counterparties of the USA-Canada regulatory partnership in the sphere of ecology, security and health protection

\begin{tabular}{|c|c|}
\hline the USA & Canada \\
\hline $\begin{array}{c}\text { U.S. Food and Drug Administration (FDA) } \\
\text { (OSHA) }\end{array}$ & Health Canada (HC) \\
\hline $\begin{array}{c}\text { U.S. Environmental Protection Agency (EPA) } \\
\text { U.S. Occupational Safety \& Health Administration } \\
\text { (FSIS) }\end{array}$ & Pesticide Management Regulatory Agency (PMRA) \\
\hline $\begin{array}{c}\text { U.S. Animal and Plant Health Inspection Service } \\
\text { APHIS) and Food Safety and Inspection Service }\end{array}$ & Canadian Food Inspection Agencies (CFIA) \\
\hline $\begin{array}{c}\text { U.S. Food and Drug Administration (FDA) } \\
\text { U.S. Department of Transportation (DOT) }\end{array}$ & Canadian Food Inspection Agencies (CFIA) \\
\hline U.S. Coast Guard (USCG) & Transport Canada (TC) \\
\hline U.S. Environmental Protection Agency (EPA) & Natural Resources Canada (NRCan) \\
\hline U.S. Department of Energy (DOE) & Natural Resources Canada (NRCan) \\
\hline $\begin{array}{c}\text { U.S. Pipeline and Hazardous Materials Safety } \\
\text { Administration (PHMSA) }\end{array}$ & Environment and Climate Change Canada (ECCC) \\
\hline U.S. Environmental Protection Agency (EPA) & Department of Fishery and Oceans (DFO) \\
\hline $\begin{array}{c}\text { National Oceanic and Atmospheric Administration } \\
\text { (NOAA) }\end{array}$ & \\
\hline
\end{tabular}

Source: built by authors upon (U.S.-Canada regulatory cooperation council, 2016).

Close trade and economic interaction between the USA and Canada was historically predefined, while NAFTA is the form of their institutionalization and a sort of platform for their realization. NAFTA was a logical result of many years of development of these relations (Table 3).

Table 3

The chronological stages of NAFTA creation

\begin{tabular}{|c|l|}
\hline Date & \multicolumn{1}{|c|}{ Steps of FTA creation } \\
\hline 1947 & $\begin{array}{l}\text { "Abbot Plan", which purpose was to stimulate and engage American investment into } \\
\text { leading industries in Canada; }\end{array}$ \\
\hline 1959 & $\begin{array}{l}\text { US-Canada Agreement on Joint Military Production to promote the Implementation of } \\
\text { American standards into Canadian production of military equipment; }\end{array}$ \\
\hline 1965 & $\begin{array}{l}\text { Agreement on the liberalization of trade in automotive products (elimination of tariffs on } \\
\text { cars, trucks, automobile tires, components and buses) between the United States and } \\
\text { Canada, which contributed to the integration of many other industries in both countries; }\end{array}$ \\
\hline \multirow{1}{*}{$1^{\text {st }}$ January, 1989 } & $\begin{array}{l}\text { The entry into force of the US-Canadian Free Trade Agreement (CUSFTA): most of the } \\
\text { tariffs were abolished immediately, while others were phased in 5-10 years, the car fleet } \\
\text { was prolonged, the national regime for investments, the ban on most import and export } \\
\text { restrictions on energy sources, etc.; }\end{array}$ \\
\hline $17^{\text {th }}$ December, 1992 & $\begin{array}{l}\text { The North American Free Trade Association Agreement (NAFTA) was signed between } \\
\text { the United States, Canada and Mexico: + in addition to CUSFTA terms: intellectual } \\
\text { property rights, limited provision of transport services and investments in the energy } \\
\text { sector of Canada, use of various methods of trade protection (anti-dumping, } \\
\text { countervailing duty, guarantees) against other countries, management of agricultural } \\
\text { supplies, etc .; }\end{array}$ \\
\hline $1^{\text {st January, 1994 }}$ & \begin{tabular}{l} 
Entry into force of the North American Free Trade Association Agreement (NAFTA). \\
\hline
\end{tabular}
\end{tabular}

Source: built by authors upon (Komar, 2016; Gunderson, 2001; Gunderson, 1999; Villareal \& Fergusson, 2015; Jeffrey \& Peterson, 2008). 
The signing of the trilateral agreement marked the beginning of a new stage in the development of the integration process both in the Western Hemisphere and in the global economy as a whole. At that time, NAFTA's formation was characterized by a number of specific features (Fig. 6).

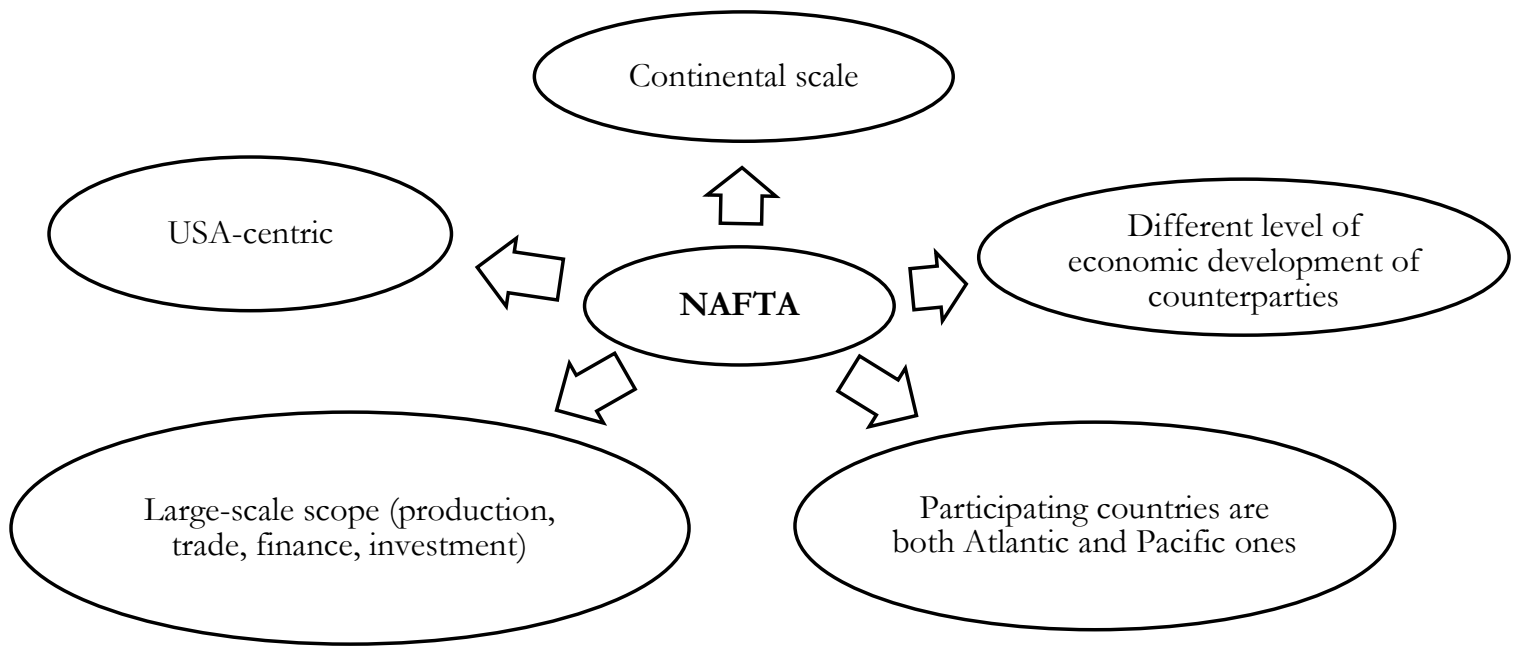

Figure 6. Specific features of North America Free Trade Agreement

Source: built by authors upon (Soloninko, 2008).

The main stimuli for integration were common economic interests, which alongside with principles of mutually beneficially relations build grounds for this agreement. The goals of agreement are the following: to eliminate barriers to trade, to create conditions for fair competition, to increase the expediency of investment, to jointly protect intellectual property rights, to introduce an effective mechanism for cooperation and resolution of conflicts, and to develop tripartite, regional and multilateral co-operation (NAFTA, 1994). The common interest of these three counterparties was the joint interest to counteract the strengthening influence of West-European integration union in the face of the EU, as well as the economic development of Asia-Pacific countries.

Both countries of North America in the framework of this union consider it as a tool for the realization of own national economic interests. The USA seek, first of all, to keep world leading economic positions, to expand duty-free market available for the sales of domestic producers, to strengthen the position of the national capital of TNCs in the economy of Mexico and Canada, to increase an access to Mexican and Canadian economic resources, to spread the influence on the countries of Latin America through Mexico, implementing a well-known pan-American policy (a political doctrine based on the idea of supposedly existing community of historical destiny, economy and culture of the USA and other countries of the American continent). Canada intended to get rid of protectionist restrictions presumed in American legislation and, thus, to increase the competitiveness of its producers' of goods at the US markets, to significantly increase trade with Mexico, to enter the markets of the countries of the Latin American region through the United States and Mexico, via the intensification of ties within the unity, to revive the economic situation within the country, to increase the pace of economic growth, to expand the limits of employment (Soloninko, 2008).

However, after 23 years of NAFTA functioning, on August 16, 2017 the USA initiated the revision of agreement (The USA, Canada and Mexico..., 2017), arguing that it is not beneficial for any of three participating countries. The fourth and fifth rounds of related negotiation had ended in October and November, 2017 respectively (Trilateral Statement..., 2017), the specific attention had been paid to the fair 
competition. The USA suggested following: tightening conditions for the terms of origin for automobile sector $(85 \%$ of respective goods should be produced within NAFTA, instead of $62,5 \%$; it is probable that $50 \%$ of them would have to be produced in the USA), any new trade agreement should be mutually approved every five years, otherwise it is cancelled and disputes are to be resolved outside the WTO (Tausche \& Domm, 2017). Under condition that Canada and Mexico agree to follow the suggestions the USA will gain the significant tools of influence over others.

It is worth mentioning, that in case of failed negotiation regarding agreement transformation, the USA mentioned the possibility to exit NAFTA several times. Moreover, two international information agencies Reuters and Bloomberg, while citing anonymous Canadian state representatives, persuaded that Ottawa is convinced that Trump intends to break the deal (Corcoran, 2018). Possibly this pushed Canada to address to the WTO with an initiative to start consultation with the USA regarding six law categories and the America practices, which contradicts the WTO membership rules. On 10 of January 2018 the respective complaint listed 188 cases of violations of the WTO Agreement on the application of anti-dumping measures, subsidies and compensatory measures, the GATT and the Dispute Settlement Rules and Procedures Understanding (The World Trade Organization, 2018). It is interesting that only two of the mentioned violations are related to Canada (those related to softwood and calendar paper), all others all other abuses are related to the import of steel, truck tires, washing machines and other products from China, Taiwan and so on. In any case, this action will be seen as a widespread attack on trade policies and the use of the US defense measures, especially as Canada itself applies widespread export subsidization practices and complicates the ongoing NAFTA reform process.

As a result of difficult negotiations, a new agreement was signed on August 30, 2018. It is noteworthy that the document is called differently, depending on the country of registration. For example, in the USA, the document is called the USMCA (United States-Mexico-Canada Agreement), in Canada - CUSMA (Canada-United States-Mexico Agreement) and in Mexico - TMEC (Tratado México-Estados UnidosCanadá).

Let's analyze the causes that lead to the crisis in relations between the USA and Mexico in the framework of ex-NAFTA. The main cause is the fact that the USA has the largest trade surplus in World starting from 1975. The deficit in goods and services equated 502 USD bn in 2016. US face deficit in trade with countries that meet at least one of the following three criteria: they can produce with lesser expenses than the USA, e.g. consumer products or crude oil; do not need product the America is specialized in, America imports more to than exports from those countries (Amadeo, 2019). The deficit in trade with Canada equals 11 USD bn, with Mexico 63 USD bn (fig. 7), which while being lower in comparison to that with China, Japan or Germany, is still too big as for FTA members.

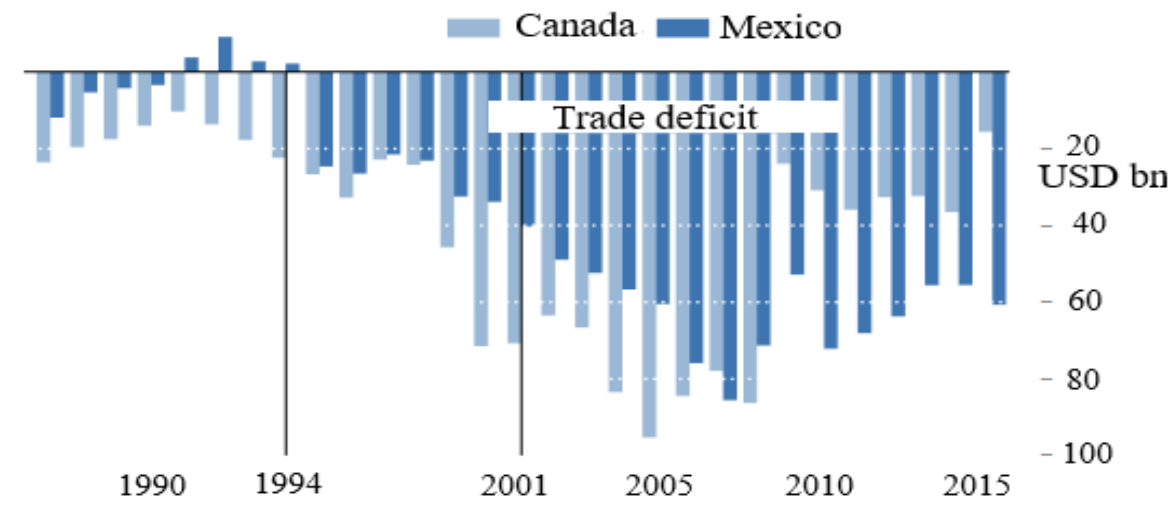

Figure 7. Balance in the US trade with ex-NAFTA country-members Source: (How Nafta Changed U.S..., 2017). 
Another reason is that even if the product is made in USA, it is generally composed of details and parts produced throughout the World. American automotive industry depends hardly on details imported mostly from Japan, China, Canada, Mexico and Germany (fig. 8). This cross-border supply chain helped to make American automotive industry competitive with respect to that of Asia and Europe, however in conditions of worsening relation with any of them, the chain is being broken, which makes production impossible.

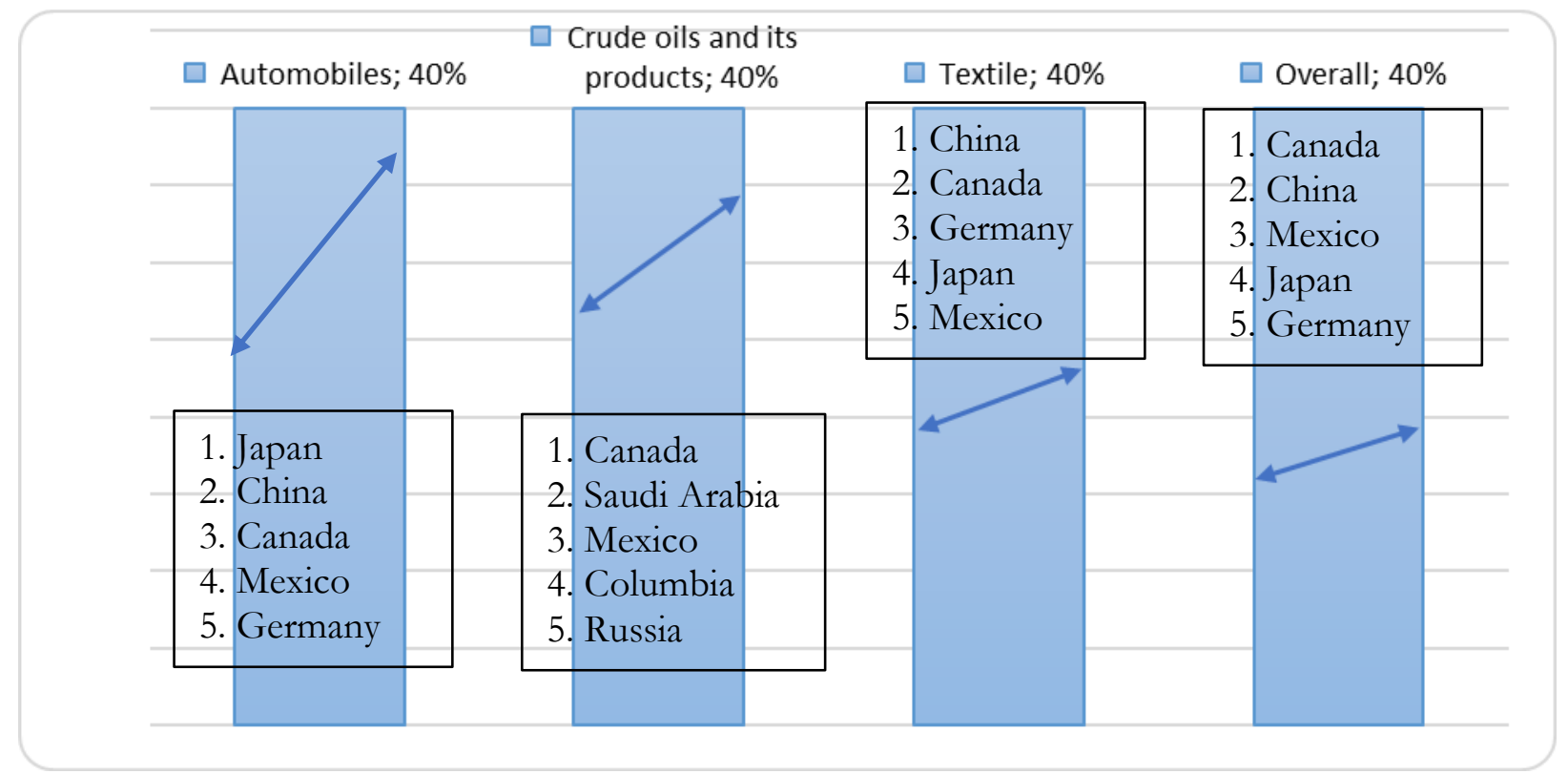

Figure 8. The share of foreign parts in finished exported products of the USA, \% Source: built by authors upon (How Nafta Changed U.S..., 2017).

Outside NAFTA critical issues appeared as a result of trade cooperation between the USA and Canada. The discussion of their resolution lasts during many years. Thus, only within the WTO 23 trade disputes were settled (Canada acted as plaintiff in 7 of them, and the United States- in 16) (World Trade Organization, 2018). However, the largest in the history of relations and still unresolved disputes remain four: on timber, aircraft, steel products and aluminum and dairy products.

Trade dispute on bolt timber is one of the longest-lasting and the most stable in countries relations, as it appeared in 1982 (Graham, 2017). The essence of the dispute is that Canadian forestry is unfairly subsidized by federal state and provinces, as the most of woods in Canada is owned by provinces. The prices for wood products are set administratively, on the opposite to the competition mechanism widespread in USA. In April 2006 the USA and China announced the preliminary decision on dispute settlement, the respective agreement was signed-Softwood Lumber Agreement (SLA). However, it ended in 2015 and any of countries did not try to prolong it. In April 2017 Trump administration announced plan to introduce import tariffs at $24 \%$ for the largest part of Canadian, stating that the companies' timber is subsidized by the government. The tariffs were applied to five companies: West Fraser Mills (largest tariff rate $24 \%$ ), Tolko Marketing and Sales, J.D. Irving, Canfor Corporation, Resolute FP Canada (Has the US started a lumber trade..., 2017). Thus, there is a possibility that after 30 years of trials to settle down the conflict, it will grow into a trade war if North American countries still rely on it.

Conflict in aviation is rather unexpected, as during decades American company Boeing competed with European consortium Arbius, but it never addressed the WTO to settle problematic issues, while it is not the case for Canadian competing company. Bombardier, aircraft producer, which head office is situated in 
Montreal, is comparably small player, competing mostly with Embraer from Brazil on the market of smaller regional reactive aircrafts. However, the last models of Bombardier, C-Series, will compete directly with Boeing 737 the first time in history (Alden, 2017). And Boeing reacted, launching a major lawsuit against Bombardier, arguing that the company received unfair subsidies from the Canadian government. The American Commission on International Trade does not plan to stop the investigation.

Canada, together with other countries, has been subject to restrictions on the export of steel and aluminum, since the D. Trump administration has established large-scale import restrictions to protect national security, thus anti-dumping investigations, including those against Ukraine, have been initiated. However, we still believe that the dispute between Canada and the US will be resolved quickly, because Canada is not a major contributor, and the volume of aluminum exports is not reaching significant scales.

Another key trade dispute, over the last two decades, is related to protectionist policy of Canada in diary industry, to quotas on the production of milk and regulated prices for dairy products. The new wave of this conflict was provoked by increase in prices by milk farmers, they argues that it was made in the framework of changing internal policy for domestic diary sector to be able to react to changes in world conjuncture. Canadian part tells that such prices do not block the import as tariffs were not changed (Robertson, 2017). In reality, Canadian system uses high prices for other diary products to be able to set lower prices for exporting products, which could be considered as unfair competition in relation to other countries.

One of problematic issues, which could appear in case of failed negotiations between countries, will be the trade in energetics, which was rather successful within the ex-NAFTA and was not put in the discussion list alongside with those in need for improvement. Both countries risk losing the preferences gained by the "proportionality" principle (Cattaneo, 2018): the United States will no longer have an automatic right to a proportional share of the energy resources of a neighboring country, and Canada will seek new markets for export of crude oil and gas. The collapse of the North American Free Trade Area could mean a return to tariffs and trade barriers preceding the agreement (which eliminated the tariffs on crude oil, gasoline, a mixture of motor fuels, jet fuels, diesel and kerosene). Therefore, the possible termination of the agreement could negatively affect the energy interconnected countries of North America.

There were two scenarios. The first one is Trump declaration of USA exiting Agreement, trying to influence counterparties in order to make necessary for USA changes, which would not be actually put in place, as it could be probably done for Paris Agreement on climate change. The second one - USA leaves the union. In such a case Canada and Mexico could cooperate on the base of bilateral FTA as it was already announced and could wait for USA coming back after Trump presidency termination. But in fact it happened according to mix of mentioned scenarios, since the USA first agreed with Mexico but Canada had caught the last bus and joined the agreement.

There is also the discussion between two countries regarding joint currency- USD and currency union, which lasts during many years. From the one side, there are preconditions for trade turnover increase, interconnection in economic sphere in case of joint currency. On the other side, the dominance of the USA just after its introduction is inevitable (Chalyi, 2012), thus Canada is against such a union and moreover is proud of its own Canadian dollar.

USA-Canada relations are not equal from the very beginning due to the size of the US economy and due to related possibilities of serious influence. The asymmetry is witnessed by the fact that Canada GDP is 10 times lower than the US GDP. For example, Canada and China, as on the end of October, 2017, terminated four rounds of negotiations on FTA creation. This provoked the dissatisfaction of US Government (Simpson, 2017) due to the fears that it will import cheap Chinese goods that will be delivered to the United States. 
However, Canadians adhere to a number of rules and principles (fig. 9), which allow them to defend their positions and to withstand the pressure during the discussion.

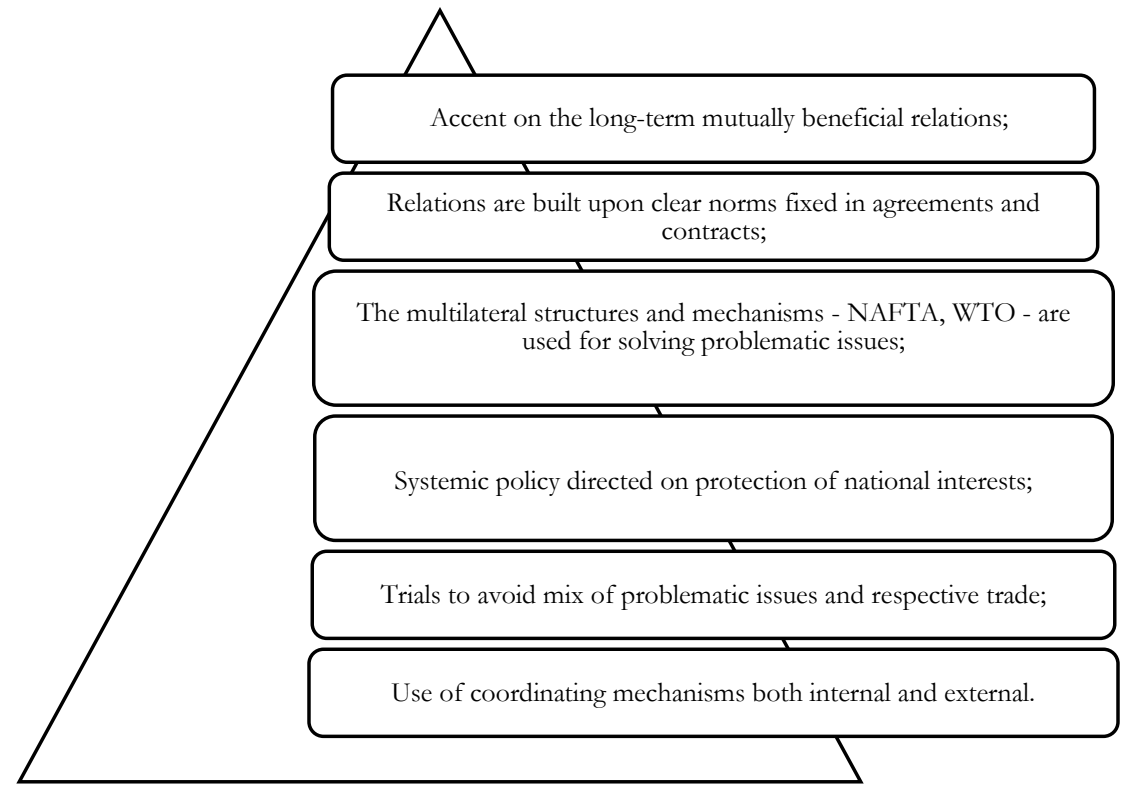

Figure 9. Principles of constructing Canadian-American relations

Source: built by authors upon (Chalyi, 2012).

To prove that Canada-USA trade relations are close, mutually beneficial and mutually effective, let's estimate the coefficient of trade connectivity, developed by A.S. Vanyushkin:

$$
K_{m}=\frac{\frac{X_{m n}}{X_{m}}}{\frac{M_{n m}}{M_{m}}},
$$

where $K_{m}$ - coefficient of trade connectivity country m with country n;

$X_{m n}$ - export of country $\mathrm{m}$ to country $\mathrm{n}$;

$X_{m}$ - total export of country m;

$M_{n m}$ - import of country $\mathrm{m}$ from country n;

$M_{m}$ - total import of country m (Vanyushkin, 2004).

Taking the USA as country $\mathrm{m}$ and Canada as country $\mathrm{n}$, lets' estimate the coefficient of trade connectivity between the USA and Canada, basing on data in USD bn: $K_{m}=\frac{\frac{278}{1444,6}}{\frac{394}{2251,35}}=1,092>1$. The coefficient bigger than 1 evidences for the connectedness of the USA trade with Canada. As the value of indicator is rather big, both countries in case of trade relations worsening or break will be hardly reoriented on other partners.

Taking into account big difference in the size of economies of North-America country-members, we consider it expedient to conduct a correlation-regression analysis and to determine whether the volume of export from Canada to the USA depends on the change in the indicator of its GDP (Table 4). 
Initial data on exports to USA and Canada GDP for 1990-2016, USD bn

\begin{tabular}{|l|c|c|c|c|c|c|}
\hline Year & $\mathbf{1 9 9 0}$ & $\mathbf{1 9 9 1}$ & $\mathbf{1 9 9 2}$ & $\mathbf{1 9 9 3}$ & $\mathbf{1 9 9 4}$ & $\mathbf{1 9 9 5}$ \\
\hline Export & 111,6 & 109,7 & 125,7 & 150,7 & 183,3 & 207,8 \\
\hline GDP & 593,9 & 610,3 & 592,4 & 577,2 & 578,1 & 604 \\
\hline $\mathbf{1 9 9 6}$ & $\mathbf{1 9 9 7}$ & $\mathbf{1 9 9 8}$ & $\mathbf{1 9 9 9}$ & $\mathbf{2 0 0 0}$ & $\mathbf{2 0 0 1}$ & $\mathbf{2 0 0 2}$ \\
\hline 223,2 & 243,9 & 269,9 & 308,1 & 359,3 & 351,8 & 345,4 \\
\hline 628,6 & 652,8 & 631,8 & 676,1 & 742,3 & 736,4 & 757,9 \\
\hline $\mathbf{2 0 0 3}$ & $\mathbf{2 0 0 4}$ & $\mathbf{2 0 0 5}$ & $\mathbf{2 0 0 6}$ & $\mathbf{2 0 0 7}$ & $\mathbf{2 0 0 8}$ & $\mathbf{2 0 0 9}$ \\
\hline 326,8 & 348,1 & 365,7 & 359,1 & 355,6 & 375,5 & 270,1 \\
\hline 892,4 & 1023,2 & 1169,4 & 1315,5 & 1464,9 & 1549,1 & 1371,2 \\
\hline $\mathbf{2 0 1 0}$ & $\mathbf{2 0 1 1}$ & $\mathbf{2 0 1 2}$ & $\mathbf{2 0 1 3}$ & $\mathbf{2 0 1 4}$ & $\mathbf{2 0 1 5}$ & $\mathbf{2 0 1 6}$ \\
\hline 298,6 & 329 & 339,2 & 357,9 & 404,7 & 402,2 & 394,4 \\
\hline 1613,5 & 1788,6 & 1824,3 & 1842,6 & 1792,9 & 1552,8 & 1538,2 \\
\hline
\end{tabular}

Source: built by authors upon [State Statistics Service of Canada, 2016; The UNCTAD, 2016).

Correlation coefficient $(r)$ for the dynamic time-series lasting for 27 years equals 0.6818839 . Correlation coefficient is higher than 0 , thus the relation is direct, meaning that with increase in export of Canada to the USA, its GDP also increased. As the value of coefficient lies within interval $0.5 \leq \mathrm{r} \geq 0.7$, the relation between indicators is noticeable. The regression equation takes the form: $y=3.5395 x+40.633$, under condition that export volume is $\mathrm{x}$, and GDP - y. It shows how the volume of Canada GDP increases, if export to Canada rises by 1 USD mln. Determination coefficient equals 0.465 (Fig. 10).

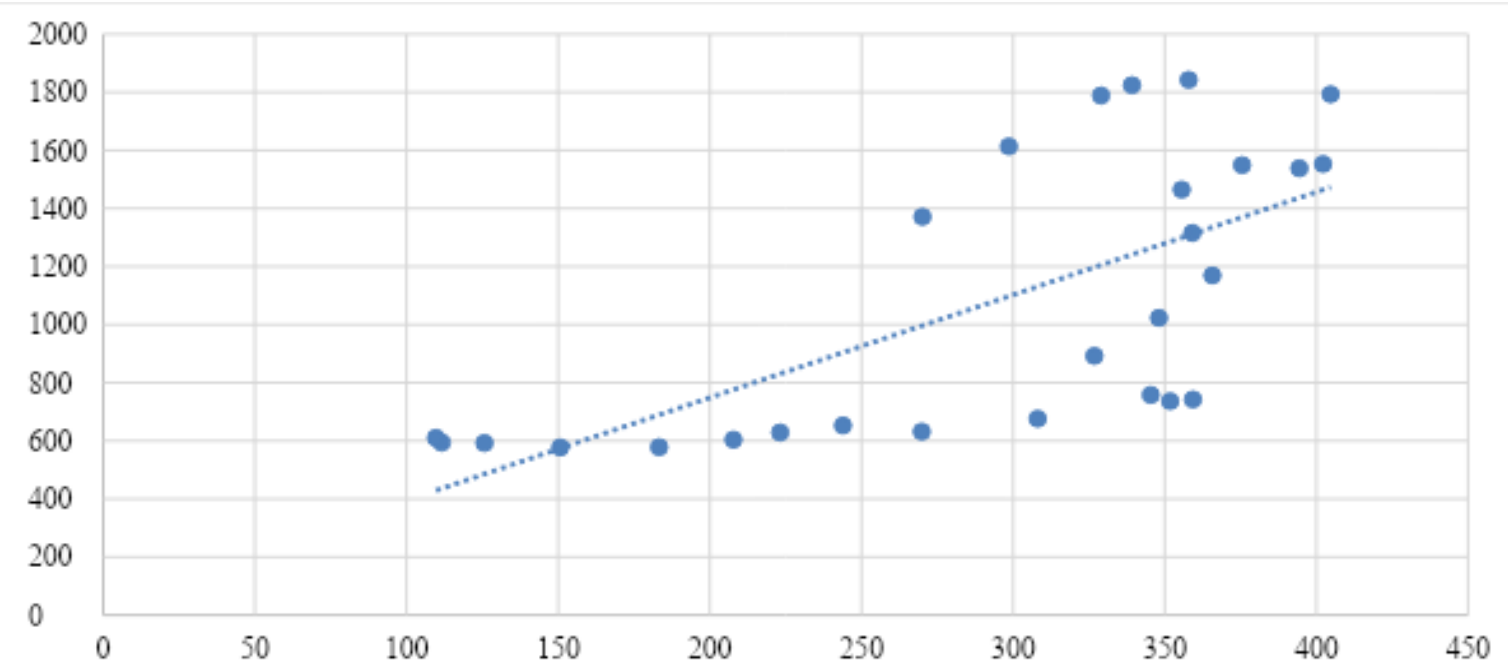

Figure 10. Regression equation and determination coefficient for Canada GDP as function of Canada exports to the USA

Source: built by authors in Microsoft Excel.

Summing up, in order to show the full picture of the trade cooperation perspectives, lets forecast export volumes from Canada to the USA for three years with the aid of time-series analysis (Fig. 11). 


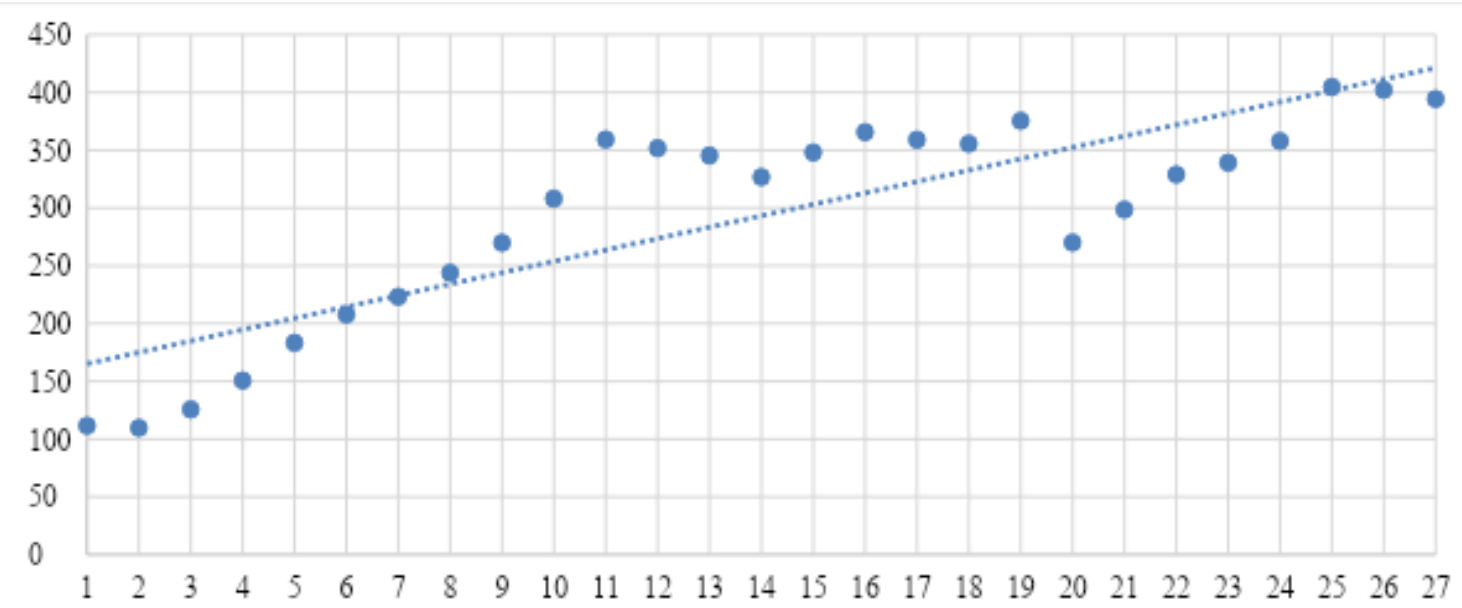

Figure 11. Trend-line of exports from Canada to the USA for 27 years

Source: built by authors in Microsoft Excel.

The forecast of export from Canada to the USA for 2017 is 431.12 USD bn, for 2018 - 440.97 USD bn, for $2019-450.82$ USD bn. Thus forecast is rather realistic as the discrepancy equals $0.001224 \%$ ((7917.3-7917.18)*100), which is lower than 5\% (Table 5).

Table5

Forecast of exports from Canada to the USA for 2017-2019

\begin{tabular}{|c|c|c|c|c|c|c|c|c|c|}
\hline $\mathbf{1 9 9 0}$ & $\mathbf{1 9 9 1}$ & $\mathbf{1 9 9 2}$ & $\mathbf{1 9 9 3}$ & $\mathbf{1 9 9 4}$ & $\mathbf{1 9 9 5}$ & $\mathbf{1 9 9 6}$ & $\mathbf{1 9 9 7}$ & $\mathbf{1 9 9 8}$ & $\mathbf{1 9 9 9}$ \\
\hline 111.6 & 109.7 & 125.7 & 150.7 & 183.3 & 207.8 & 223.2 & 243.9 & 269.9 & 308.1 \\
\hline 1 & 2 & 3 & 4 & 5 & 6 & 7 & 8 & 9 & 10 \\
\hline 165.19 & 175.04 & 184.89 & 194.74 & 204.59 & 214.44 & 224.28 & 234.13 & 243.98 & 253.83 \\
\hline $\mathbf{2 0 0 0}$ & $\mathbf{2 0 0 1}$ & $\mathbf{2 0 0 2}$ & $\mathbf{2 0 0 3}$ & $\mathbf{2 0 0 4}$ & $\mathbf{2 0 0 5}$ & $\mathbf{2 0 0 6}$ & $\mathbf{2 0 0 7}$ & $\mathbf{2 0 0 8}$ & $\mathbf{2 0 0 9}$ \\
\hline 359.3 & 351.8 & 345.4 & 326.8 & 348.1 & 365.7 & 359.1 & 355.6 & 375.5 & 270.1 \\
\hline 11 & 12 & 13 & 14 & 15 & 16 & 17 & 18 & 19 & 20 \\
\hline 263.68 & 273.53 & 283.38 & 293.23 & 303.08 & 312.93 & 322.78 & 332.63 & 342.47 & 352.32 \\
\hline $\mathbf{2 0 1 0}$ & $\mathbf{2 0 1 1}$ & $\mathbf{2 0 1 2}$ & $\mathbf{2 0 1 3}$ & $\mathbf{2 0 1 4}$ & $\mathbf{2 0 1 5}$ & $\mathbf{2 0 1 6}$ & $\mathbf{2 0 1 7}$ & $\mathbf{2 0 1 8}$ & $\mathbf{2 0 1 9}$ \\
\hline 298.6 & 329 & 339.2 & 357.9 & 404.7 & 402.2 & 394.4 & & & \\
\hline 21 & 22 & 23 & 24 & 25 & 26 & 27 & 28 & 29 & 30 \\
\hline 362.17 & 372.02 & 381.87 & 391.72 & 401.57 & 411.42 & 421.27 & 431.12 & 440.97 & 450.82 \\
\hline
\end{tabular}

Source: estimated by authors in Microsoft Excel.

\section{CONCLUSION}

The Canada-USA trade relations are asymmetric ones due to difference in economies' size, but are beneficial and highly efficient, as countries are the biggest trade partners and investors of each other. The perspectives of future cooperation hardly depend on the results of negotiations regarding the next improvement of USMCA. Despite the positive conclusion of negotiations on NAFTA's reform and its transformation into USMCA / CUSMA, Canada still has to build a rational policy in order not to become the fifty-first state of America within the currency and, then, political union. In light of the discontent with the agreement by the Government and the population of Canada, there is a high probability of continuing negotiations to further improvement of the USMCA. 


\section{REFERENCES}

Alden, E. (2017). 4 major trade conflicts the US has with Canada. Business insider. Retrieved from http://www.businessinsider.com/4-major-trade-conflicts-the-us-has-with-canada-2017-6.

Amadeo, K. (January 21, 2019). U.S. Trade Deficit by Country: Current Statistics and Issues. The Balance. Retrieved from https://www.thebalance.com/trade-deficit-by-county-3306264.

Bilan, Y. (2009). Increase Diversification Through Strengthened Enabling Environment for Entrepreneurship: a Focus on Skill Endowments and Export Orientation (Example of Hungary and Poland). Economics and Sociology, 2(2), 33-45.

Chalyi, V. (2012). Canada - USA: asymmetric experience of relations. Džerkalo Tyz̧nya, 42. Retrieved from https://dt.ua/POLITICS/kanada_sha_korisniy_dosvid_asimetrichnih_vidnosin.html. (In Ukrainian)

Cattaneo, C. (January 16, 2018). «Shooting themselves in the foot»: How NAFTA's collapse could disrupt U.S.-Canada energy trade. Financial Post. Retrieved from http://business.financialpost.com/commodities/energy/shootingthemselves-in-the-foot-how-naftas-collapse-could-disrupt-u-s-canada-energy-trade.

Corcoran, T. Canada is now playing hardball on trade with the U.S. - good. (January 10, 2018). Financial Post. Retrieved from http://business.financialpost.com/opinion/terence-corcoran-canada-is-now-playing-hardball-on-tradewith-u-s-good.

Desjardins, J. (2017). The Numbers Behind the World's Closest Trade Relationship. Visual Capitalist. Retrieved from http://www.visualcapitalist.com/closest-trade-relationship-usa-canada.

Dzialo, J., Gawronska-Nowak, B., Jura, J. (2017). Social Debate on Free Trade Agreements: Illusions Versus Reality. Economics and Sociology, 10(3), 116-135. doi:10.14254/2071-789X.2017/10-3/9

Graham, D.A. (April 26, 2017). Why Is Trump Risking a Trade War With Canada? The Atlantic. Retrieved from https://www.theatlantic.com/international/archive/2017/04/why-is-trump-starting-a-trade-war-withcanada/524265.

Jeffrey, J., \& Peterson, S. (November 21-23, 2008). The North American Free Trade Agreement: Time for a Change? 7th Annual North American Regional Meeting. The Trilateral Commission. Ottawa. 1-21.

Has the US started a lumber trade war with Canada? (April 26, 2017). The BBC News. Retrieved from http://www.bbc.com/news/world-us-canada-39708779.

How Nafta Changed U.S. Trade With Canada and Mexico. (2017). The New York Times. Retrieved from https://www.nytimes.com/interactive/2017/business/nafta-canada-mexico.html.

Gawronska-Nowak, B., Beck, K., \& Valdivieso, P. (2019). Expert knowledge status quo in the Internet provided public debate on Free Trade Agreements. Meta analysis of Polish literature. Economics and Sociology, 12(1), 248-261.

doi:10.14254/2071-789X.2019/12-1/14

Gunderson, M. (2001). North American Economic Integration and Globalization. A chapter in The State of Economics in Canada: Festschrift in Honour of David Slater. The Centre for the Study of Living Standards, 355-375. Retrieved from http://www.csls.ca/events/slt01/gunderson.pdf. ISBN: 0-88911-942-2.

Gunderson, M. (3 January, 1999). Labour Standards, Income Distribution and Trade. Integration and Trade, 82-104.

Kim, H. M. (2018). Economic growth and tariff levels in the United States: A Granger causality analysis. Journal of International Studies, 11(4), 79-92. doi:10.14254/2071-8330.2018/11-4/6

Komar, N.V. (2016). Characteristics of forming a free trade zone in North America. Bulletin of the Ternopil National Economic University, 1, 110-117. (In Ukrainian)

Lukyanenko, D.G., Poruchnyk, A.M., \& Stolyarchuk, Ya.M. (2014). International Economics. Kyiv: KNEU. (In Ukrainian)

Lynch, K. (2017). U.S.-Canada International Trade. American Express. Retrieved from https://www.americanexpress.com/us/content/foreignexchange/articles/international-trade-united-statescanada

Moroz, S., Nagyova, L., Bilan, Y., Horska, E., \& Polakova, Z. (2017). The current state and prospects of trade relations between Ukraine and the European Union: the Visegrad vector. Economic Annals-XXI, 163(1-2), 14-21.

North American Free Trade Agreement. Retrieved from https://www.nafta-sec-alena.org/Home/Texts-of-theAgreement/North-American-Free-Trade-Agreement.

Official Website of the State Statistics Service of Canada. Canada's merchandise trade with the U.S. by state. Retrieved from https://www.statcan.gc.ca/pub/13-605-x/2017001/article/14841-eng.htm. 
Official Website of the Statistics Bureau of Canada USA. Data and Statistics about the United States. Retrieved from https://www.usa.gov/statistics.

Official website of World Trade Organization. Retrieved from https://www.wto.org/index.htm

Pasmor, M.R., Babenko, V.O., \& Sidorov, V.I. (2016). Trade and economic component of regional economic processes in the conditions of globalization. Business Inform, 4, 31-37. (In Ukrainian)

Top 10 US Exports to Canada. Retrieved from http://www.worldsrichestcountries.com/top_us_exports.html.

U.S.-Canada regulatory cooperation council. Retrieved from https://www.trade.gov/RCC.

Villareal, M.A., \& Fergusson, I.A. (April 16, 2015). The North American Free Trade Agreement (NAFTA). Congressional Research Service, 1-33.

Soloninko, K.P. (2008). International Economics. Kyiv: Condor. (In Ukrainian)

The USA, Canada and Mexico began to review the terms of the FTA. (2017). Retrieved from https://tsn.ua/svit/sshakanada-i-meksika-rozpochali-pereglyad-umov-zvt-977325.html. (In Ukrainian)

Trilateral Statement on the Conclusion of the Fourth Round of NAFTA Negotiations. (2017). Retrieved from https://ustr.gov/about-us/policy-offices/press-office/press-releases/2017/october/trilateral-statementconclusion.

Tausche, K., \& Domm, P. (2017). US trade deal with Canada, Mexico on 'thin ice' as new round of talks begin. CNBC LLC. Retrieved from https://www.cnbc.com/2017/10/10/u-s-trade-deal-with-canada-mexico-on-thin-iceas-new-round-of-talks-begin.html.

The World Trade Organization. (January 10, 2018). Canada Files WTO Complaint Over US Trade Remedies. Retrieved from https://www.wto.org/english/news_e/news18_e/ds535rfc_10jan18_e.htm.

Robertson, L. (April 28, 2017). The U.S.-Canada Dairy Dispute. FactCheck. Retrieved from http://www.factcheck.org/2017/04/u-s-canada-dairy-dispute.

Simpson, K. (October 27, 2017). Trudeau dismisses concerns free trade with China will hurt Canada-U.S. relationship. CBC News. Retrieved from https://www.cbc.ca/news/politics/james-moore-china-nafta-plan-1.4374026.

Vanyushkin, A.P. (2004). Identification of development problems prior to the creation of integration unions. Culture of the Peoples of Black Sea, 56(1), 97-100. (In Ukrainian)

UNCTAD. Official website of United Nations Conference on Trade and Development - UNCTAD. Retrieved from http://unctadstat.unctad.org/wds/TableViewer/tableView.aspx.

Yatsenko, O., Nitsenko, V., Karasova, N., James Jr, H. S., \& Parcell, J. L. (2017). Realization of the potential of the Ukraine-EU free trade area in agriculture. Journal of International Studies, 10(2), 258-277.

Yatsenko, O., Nitsenko, V., Mardani, A., Streimikiene, D., \& Tananaiko, T. (2019). Global Risks of Trade and Economic Cooperation of Ukraine With Countries of the Northern American Region. Montenegrin Journal of Economics, 15(3), 217-225. 